\title{
Non-Breast Milk Feeding in Developing Countries: Challenge from Microbial and Chemical Contaminants
}

\author{
Gerardo Weisstaub Ricardo Uauy \\ Instituto de Nutrición y Tecnologia de los Alimentos (INTA), University of Chile, Santiago, Chile
}

\section{Key Words}

Infant feeding $\cdot$ Microbial $\cdot$ Chemical $\cdot$ Contaminants

\begin{abstract}
Complementary foods based on cow's milk or gruels consumed by children in developing countries are often contaminated by bacteria during preparation, and ambient temperature rapidly increases microbial load. Thus infant formula or other weaning foods may cause diarrhea in young infants accounting for $25-33 \%$ of all deaths $<5$ years globally. Environmental chemicals such as metals ( $\mathrm{As}, \mathrm{Pb}, \mathrm{Cu}$ ) and nitrates can cause vomiting/diarrea. Polychlorinated biphenyls derived from plastics, present in formula and/or breast milk, are endocrine disruptors (the potential threats are not fully quantifiable). The prevailing view is that benefits from breastfeeding outweigh potential risks.
\end{abstract}

Copyright $\odot 2012$ S. Karger AG, Basel

\section{Microbiological Contaminants}

Cow's milk and breast milk substitutes are often fed at home or at infant care centers to young infants who are not exclusively breastfed [1]. After 6 months, all infants need complementary foods to fulfill their protein and mi- cronutrient needs [2]. Complementary foods are commonly based on cow's milk formulations, or starchy gruels often prepared in settings where environmental sanitation is poor or water is contaminated [3]. If hygiene is not optimal, products easily become contaminated at the moment of preparation, and given prevailing ambient temperature in most developing countries, bacterial proliferation rapidly increases the microbial load [4]. Thus, infant formulas or other weaning foods may be massively contaminated when consumed.

This occurs even in hospital services, since the water used for the preparation of formula and food may be contaminated with bacteria at its origin; counts can rise rapidly once milk is in a liquid form. Bacterial doubling times are commonly 20-30 min under room temperature conditions. Reconstituted formula, even if stored in the refrigerator, may show increasing bacterial counts over time if contaminated upon preparation [5]. Unless hygienic practices are strictly followed and all personnel is routinely monitored for potential pathogens by culturing hands, throat, and feces, microbial contamination of formula or other foods is not uncommon. The manipulation of human milk and infant formula, even when done in hospital milk kitchens, may be a source of contamination as shown in figure $1[6,7]$.

\section{KARGER}

Fax +4161306 1234

E-Mail karger@karger.ch

www.karger.com
(C) 2012 S. Karger AG, Basel

0250-6807/12/0603-0215\$38.00/0

Accessible online at:

www.karger.com/anm
Ricardo Uauy, $\mathrm{MD}, \mathrm{PhD}$

Instituto de Nutrición y Tecnologia de los Alimentos (INTA)

University of Chile, PO Box 138-11

Macul 5540, Santiago (Chile)

E-Mail ricardo.uauy@lshtm.ac.uk 
Fig. 1. Distribution of bacterial contamination of hands of milk kitchen health workers and milk formula destined to feeding infants in pediatric hospitals classified as pathogenic or non-pathogenic in Salvador Bahia, Brazil. Data obtained from Cairo et al. [6].

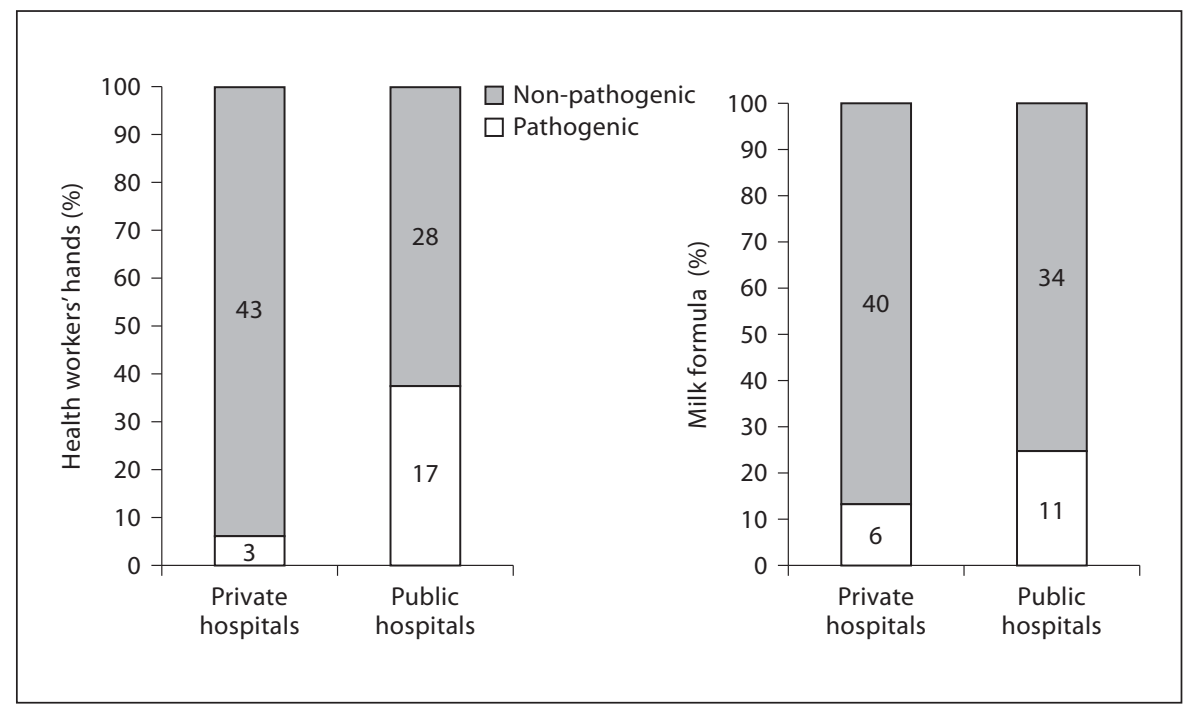

This represents a major threat to children receiving artificial feeding, especially those who may be more vulnerable to infectious diseases because of malnutrition, being born small, and/or due to comorbidities [8]. Diarrheal disease due to infection is one of the main causes of death of young infants in developing countries [9] accounting for $25-33 \%$ of all deaths at $<5$ years of age [10].

A common misconception is that cow's milk formula is responsible for these deaths; however, the evidence clearly indicates that if formula is prepared adequately under hygienic conditions and stored appropriately if not intended for immediate consumption, the hazard is negligible or significantly reduced. Hospital-borne outbreaks of gastroenteritis are of special concern since the distribution of milk formula in the hospital may serve as a carrier of infections [11]. Most outbreaks in hospital settings are caused by foods prepared by the hospital milk kitchens contaminated by pathogenic bacteria (Staphylococcus aureus, Clostridium spp., Salmonella spp., Yersinia enterocolitica, Shigella spp., and Escherichia coli) [12]. Additionally, Enterobacter sakazakii has been identified as a pathogenic contaminant of milk [13]. In developing countries as well as in developed countries, hospital personnel in charge of milk preparation have been found to be asymptomatic carriers of pathogenic microorganisms and thus may represent a continuous source of contamination [14].

Contamination of foods may occur at any stage, from the arrival of the raw ingredients to the final delivery to the patient. Therefore, good hygiene is crucial through- out the chain of events. Hand washing with water and soap is one of the simplest and most effective measures to prevent infections. Alcohol can also be used as a hand sanitizer, preferably after hand washing to complement antisepsis [15]. Studies in developing countries have characterized the bacterial flora colonizing the hands, pharynx, and feces of hospital staff. In most cases, it is these microbes that end up in the contaminated milk or food consumed by children. Thus, it is of vital importance to periodically monitor healthcare staff and all persons responsible for formula preparation; protocols in place should address the challenge of microbial safety [16]. The need to promote clean water and environmental sanitation is vital [17].

\section{Chemical Contaminants of Formula}

Arsenic, copper, lead, polychlorinated biphenyls (PCBs), and phthalates present in the water naturally or as contaminants, or derived from containers used to store liquid formula, also pose potential health risks for infants and young children.

\section{Arsenic}

In some regions, arsenic, a natural element part of the earth's crust, may be found in water that has flowed or filtered through arsenic-rich rocks. Drinking arsenicrich water over a period of time is toxic. Conditions such as poor sanitation and malnutrition aggravate the health effects of arsenic. Acute poisoning is not well defined; 
Fig. 2. Lung cancer mortality in high arsenic exposure areas of northern Chile compared to low arsenic exposure areas at different age categories. Duration of exposure was similar for all high arsenic exposure groups. The comparison risk group was age controlled with a low arsenic exposure geographic area. As = Arsenic; $A M R=o b-$ served/expected age-adjusted mortality rate. Data obtained from Marshall et al. [19].

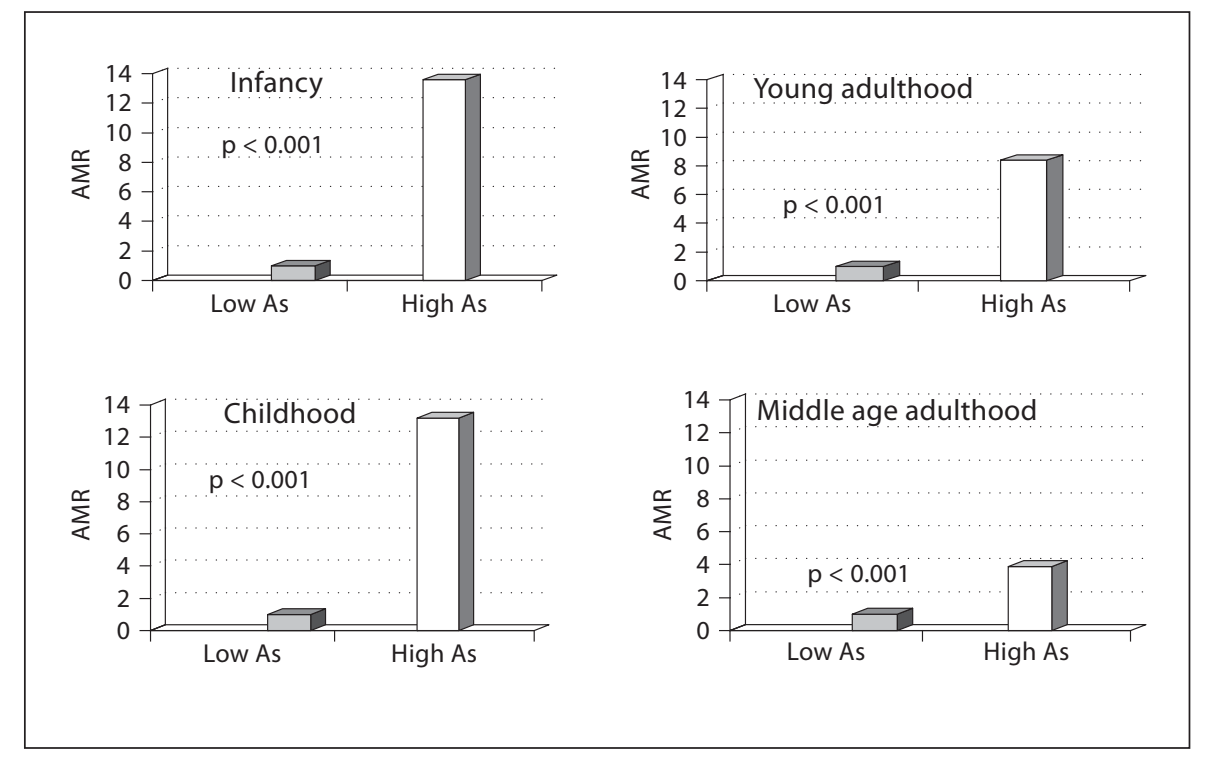

however, it has been reported in Argentina, Bangladesh, China, Chile, Ghana, Hungary, India, Mexico, Thailand, and the USA $[18,19]$.

In Bangladesh, West Bengal, and other areas of the world, because of concerns with water-borne disease (diarrhea, dysentery, typhoid, cholera, and hepatitis), programs to provide 'safe' drinking water through wells have been implemented. However, microbiologically safe well water has brought a serious unintended consequence: massive exposure of large segments of the population including infants and young children to arsenic, giving rise to a major health problem. Early symptoms include abdominal pain, vomiting, and diarrhea, muscular pain, weakness, and flushing of the skin. These are followed by numbness and tingling of the extremities, muscular cramping, and the appearance of a papular erythematous rash [20]. The latency for arsenic-caused skin lesions is typically about 10 years. Chronic toxicity from arseniccontaminated water is beyond skin depth; it includes peripheral neuropathy, cancers of the skin, bladder, and lungs, with a typical latency of more than 20 years. Figure 2 illustrates the special sensitivity of young children to cancer after early exposure to arsenic. In Bangladesh, about 75 million people are at risk from drinking arseniccontaminated water [21]. This is likely the largest mass poisoning of a population in history. Documented health consequences range from skin lesions to various forms of cancers, neurological effects, cardiovascular and pulmonary disease, and diabetes [22].

Non-Breast Milk Feeding in Developing Countries

\section{Copper}

The contribution of water to daily copper intake may be high in young infants since they consume proportionally more water than adults [23]. If formula is not fortified with copper, water contributes over $50 \%$ of total copper daily intake. Toxic effects associated with copper in children not suffering from Wilson disease are extremely rare. At lower doses, early adverse responses include nausea and vomiting due to vagal stimulation. Evidence of acute adverse effects served to establish $2 \mathrm{mg} / \mathrm{l}$ copper as the WHO safe limit in drinking water [24]. Indian childhood cirrhosis (ICC) and idiopathic chronic toxicosis (ICT) represent examples of chronic copper toxicity associated with artificial feeding [25]. The former is related to high exposure to copper due to consumption of animal milk stored or heated in copper or copper alloy containers [26]. Intakes associated with cirrhosis were 50-100 times higher than normal $(930 \pm 36 \mu \mathrm{g} / \mathrm{kg}$ per day). This is high enough to explain by itself liver damage in the absence of genetic abnormalities of copper metabolism. The condition has dramatically declined after instructing the population to avoid using copper vessels to store and/or heat milk; no cases have been diagnosed after 1974 in Pune [27]. ICT-associated infantile cirrhosis is extremely rare; based on prospective autopsy data from Germany, it occurs in 1:500,000 to 1:1,000,000 live births [28]. Sporadic cases of childhood cirrhosis have also been reported elsewhere; in some cases, high copper in drinking water was demonstrated post facto. Increased genetic susceptibility has been raised based on the fact that other children 
living in the same geographical areas similarly exposed did not develop liver abnormalities. In Austrian Tyrol, between 1900 and 1974, when copper utensils were used to prepare infant foods, 138 infants and young children died from liver cirrhosis attributed to a high chronic copper exposure [29]. However, since several cases occurred in consanguineous marriages, a genetic susceptibility factor has been suggested. ICC and ICT remain diseases of uncertain etiology; the most likely explanation for these conditions appears to be a combination of a genetic defect in copper metabolism and high copper intake; the relative contribution of each remains to be determined.

\section{Lead}

Lead in water used to reconstitute formula can cause elevations in blood lead levels if used from the hot water tap or boiled [30]. There is a 4- to 6-point IQ drop for every $10 \mu \mathrm{g} / \mathrm{dl}$ increase in blood lead levels [31].

\section{Nitrates}

Nitrates are converted to nitrites by the colonic flora resulting in a rise in methemoglobin that fails to bind molecular oxygen. This risk increases if young infants under 6 months are fed baby food with high concentrations of nitrates. Infants fed formula reconstituted with nitrate-contaminated water are at risk for potentially fatal methemoglobinemia [32].

\section{Polychlorinated Biphenyls}

PCB compounds are endocrine-disrupting chemicals. Most have estrogen-like activity or block androgen action [33]. Phthalates are used as plasticizers and are testicular toxins as well as estradiol imitators. Bisphenol-A (B-A) is used in the production of polycarbonate plastics and has been found in plastic baby bottles [34]. Both can leach from the container and are known to be estrogenic since 1938. B-A is used to coat the metal can in baby food or infant formula cans. They have a high affinity for lipids and have been shown to leach into the content of cans during the autoclaving process.

\section{Conclusion}

The increasing number of environmental chemicals measured in breast milk is a consequence of improved analytical capabilities and the increased interest in biomonitoring. It has generally been concluded that the benefit to the infant from breastfeeding outweighs potential risks associated with environmental chemical exposures associated with breastfeeding. However, there have been reports of subtle effects on infants associated with chemicals in breast milk. The essential conclusion for healthcare providers and new parents is that in studies of breastfed versus formula-fed infants across time, including times when levels of environmental chemicals such as dioxins were higher, beneficial effects associated with breastfeeding have been found [35].

\section{Disclosure Statement}

R.U. declares no conflicts of interest that are related to the content of this paper. However, he has conducted research in topics related to this publication funded by the Chilean National Science Fund (Fondecyt) on nutritional effects and metabolic tolerance to copper in infants and on nutritional components of human milk. $\mathrm{He}$ has also conducted research funded by the Chilean National Science Fund (Fondecyt) and the Chilean Ministry of Health on environmental contaminants and potential health effects. G.W. has nothing to disclose.

\section{References}

1 Martinez JA, Ballew MP: Infant formulas. Pediatr Rev 2011;32:179-189.

2 Butte N, Lopez-Alarcon MG, Garza C: Nutrient Adequacy of Exclusive Breastfeeding for the Term Infant during the First Six Months of Life. Geneva, World Health Organization, 2002.

-3 Wijndaele K, Lakshman R, Landsbaugh JR, Ong KK, Ogilvie D: Determinants of early weaning and use of unmodified cow's milk in infants: a systematic review. J Am Diet Assoc 2009; 109:2017-2028.
4 Redmond EC, Griffith CJ: The importance of hygiene in the domestic kitchen: implications for preparation and storage of food and infant formula. Perspect Public Health 2009; 129:69-76.

5 Agostoni C, Axelsson I, Goulet O, Koletzko B, Michaelsen KF, Puntis JW: Preparation and handling of powdered infant formula: a commentary by the ESPGHAN Committee on Nutrition. JPGN 2004;39:320-322.
6 Cairo RC, Silva LR, Andrade CF, Barberino MG, Bandeira AC, Santos KP, Diniz-Santos DR: Bacterial contamination in milk kitchens in pediatric hospitals in Salvador, Brazil. Braz J Infect Dis 2008;12:217-221.

7 Palcich G, de Moraes Gillio C, Aragon-Alegro LC, Pagotto F; Farber JM, Landgraf M: Enterobacter sakazakii in dried infant formulas and milk kitchens of maternity wards in São Paulo, Brazil. J Food Prot 2009;72:3742.

-8 Solomons N: Malnutrition and infection: an update. Br J Nutr 2007;98(suppl 1):S5S10. 
9 Chisti JM, Pietroni MA, Smith JH, Bardhan PK, Salam MA: Predictors of death in underfive children with diarrhoea admitted to a critical care ward in an urban hospital in Bangladesh. Acta Paediatr 2011, DOI: 10.1111/j.1651-2227.2011.02368.

10 Black RE, Morris SS, Bryce J: Where and why are 10 million children dying every year? Lancet 2003;361:2226-2234.

-11 Heuvelink AE, van Heerwaarden C, Zwartkruis-Nahuis A, Tilburg JJ, Bos MH, Heilmann FG, Hofhuis A, Hoekstra T, de Boer E: Two outbreaks of campylobacteriosis associated with the consumption of raw cows' milk. Int J Food Microbiol 2009;134:70-74.

-12 Scavia G, Staffolani M, Fisichella S, Striano G, Colletta S, Ferri G: Enteroaggregative Escherichia coli associated with a foodborne outbreak of gastroenteritis. J Med Microbiol 2008;57:1141-1146.

-13 Al-Holy MA, Shin JH, Osaili TM, Rasco BA: Evaluation of a new enrichment broth for detection of Cronobacter spp. in powdered infant formula. J Food Prot 2011;74:387-393.

14 Todd EC, Greig JD, Bartleson CA, Michaels BS: Outbreaks where food workers have been implicated in the spread of foodborne disease. Part 4. Infective doses and pathogen carriage. J Food Prot 2008;71:2339-2373.

15 Boyce JM, Pittet D; Healthcare Infection Control Practices Advisory Committee; HICPAC/SHEA/APIC/IDSA Hand Hygiene Task Force: Guideline for Hand Hygiene in Health-Care Settings: Recommendations of the Healthcare Infection Control Practices Advisory Committee and the HICPAC/ SHEA/APIC/IDSA Hand Hygiene Task Force. Society for Healthcare Epidemiology of America/Association for Professionals in Infection Control/Infectious Diseases Society of America. MMWR Recomm Rep 2002; 51:1-45.

-16 Owusu-Ofori A, Jennings R, Burgess J, Prasad PA, Acheampong F, Coffin SE: Assessing hand hygiene resources and practices at a large African teaching hospital. Infect Control Hosp Epidemiol 2010;31:802-808.
Kusachi S, Sumiyama Y, Arima Y, Yoshida Y, Tanaka H, Nakamura Y, Nagao J, Saida Y, Watanabe $\mathrm{M}$, et al: Creating a manual for proper hand hygiene and its clinical effects. Surg Today 2006;36:410-415.

18 Smith AH, Marshall G, Yuan Y, Ferreccio C, Liaw J, von Ehrenstein O, Steinmaus C, Bates MN, Selvin S: Increased mortality from lung cancer and bronchiectasis in young adults after exposure to arsenic in utero and in early childhood. Environ Health Perspect 2006; 114:1293-1296.

19 Marshall G, Ferreccio C, Yuan Y, Bates MN, Steinmaus C, Selvin S, Liaw J, Smith AH: Fifty-year study of lung and bladder cancer mortality in Chile related to arsenic in drinking water. J Natl Cancer Inst 2007;99: 920-928.

20 Smith AH, Steinmaus CM: Health effects of arsenic and chromium in drinking water: recent human findings. Annu Rev Public Health 2009;30:107-122.

-21 Sohel N, Persson LA, Rahman M, Streatfield PK, Yunus M, Ekström EC, Vahter M: Arsenic in drinking water and adult mortality: a population-based cohort study in rural Bangladesh. Epidemiology 2009;20:824-830.

22 Chen Y, Graziano JH, Parvez F, Liu M, Slavkovich V, Kalra T, Argos M, Islam T, Ahmed A, et al: Arsenic exposure from drinking water and mortality from cardiovascular disease in Bangladesh: prospective cohort study. BMJ 2011;342:d2431.

23 Uauy R, Olivares M, Gonzalez M: Essentiality of copper in humans. Am J Clin Nutr 1998;67(5 suppl):952S-959S.

24 WHO: IPCS EHC (International Program for Chemical Safety, Environmental Health Criteria) No. 228. Principles and methods for the assessment of risk from essential trace elements. Geneva, World Health Organization, 2002.

25 Scheinberg IH, Sternlieb I: Is non-Indian childhood cirrhosis caused by excess dietary copper? Lancet 1994;344:1002-1004.

26 Uauy R, Maass A, Araya M: Estimating risk from copper excess in human populations. AJCN 2008;88:867S-871S.

27 Pandit A, Bhave S: Present interpretation of the role of copper in Indian childhood cirrhosis. Am J Clin Nutr 1996;63:830S-835S.
28 Dieter HH, Schimmelpfennig W, Meyer E, Tabert M: Early childhood cirrhosis (ECC) in Germany between 1982 and 1994 with special consideration of copper etiology. Eur J Med Res 1999;4:233-242.

29 Wijmenga C, Müller T, Murli IS, Brunt T, Feichtinger H, Schönitzer D, Houwen RH, Müller W, Sandkuijl LA, Pearson PL: Endemic Tyrolean infantile cirrhosis is not an allelic variant of Wilson's disease. Eur J Hum Genet 1998;6:624-628.

30 Work Group of the Advisory Committee on Childhood Lead Poisoning Prevention: A review of evidence of health effects of blood lead levels $<10 \mu \mathrm{g} / \mathrm{dl}$ in children. Atlanta, GA, US Centers for Disease Control and Prevention, National Center for Environmental Health, 2004.

-31 Lanphear BP, Hornung R, Khoury J, Yolton $\mathrm{K}$, Baghurst P, Bellinger DC, Canfield RL, Dietrich KN, Bornschein R, et al: Low-level environmental lead exposure and children's intellectual function: an international pooled analysis. Environ Health Perspect 2005; 113:894-899.

32 Greer FR, Shannon M; American Academy of Pediatrics, Committee on Nutrition, Committee on Environmental Health: Infant methemoglobinemia: the role of dietary nitrate in food and water. Pediatrics 2005; 116:784-786

33 Pinto B, Garritano SL, Cristofani R, Ortaggi G, Giuliano A, Amodio-Cocchieri R, Cirillo T, De Giusti M, Boccia A, Reali D: Monitoring of polychlorinated biphenyl contamination and estrogenic activity in water, commercial feed and farmed seafood. Environ Monit Assess 2008;144:445-453.

34 Kubwabo C, Kosarac I, Stewart B, Gauthier BR, Lalonde K, Lalonde PJ: Migration of bisphenol A from plastic baby bottles, baby bottle liners and reusable polycarbonate drinking bottles. Food Addit Contam Part A Chem Anal Control Expo Risk Assess 2009; 26:928-937.

35 Van Rossum CTM, Büchner FL, Hoekstra J: Quantification of health effects of breastfeeding: review of the literature and model simulation. RIVM report 350040001/2005. Bilthoven, RIVM, 2006. 